\title{
MUITA HISTÓRIA COM POUCAS LETRAS \\ um olhar literário ao Presépio do Pipiripau
}

\author{
Mariângela de Andrade Paraizo \\ UFMG
}

\begin{abstract}
RESU MO
Este trabalho propõe uma leitura do Presépio do Pipiripau, tomando como ponto de partida as obras literárias publicadas sobre ele, bem como outras leituras feitas através de fotografias, pinturas ou cinema. Utilizando-se das teorias de Italo Calvino e Ricardo Piglia, defende a idéia de que se podem ler as várias histórias entrelaçadas no Pipiripau à luz da teoria literária e dos estudos sobre a intermidialidade.

\section{PALAVRAS - CHAVE}

Obra folclórica, presépio "modernista", história(s), leituras, re-presentação verbal e visual, teoria da literatura
\end{abstract}

No es un mapa, ni una maqueta, es una máquina sinóptica; toda la ciudade está ahí, concentrada en si misma, reducida a su esencia.

Ricardo Piglia, El último lector

$\mathbf{E}_{\mathrm{m}}$ visita ao Presépio do Pipiripau, ouvindo a monitora contar que quase todas as figuras adquiriam movimento quando o maquinário era ligado, uma criança perguntou se elas falavam. A monitora respondeu que não, o que é correto, se consideramos o que provavelmente essa criança esperava. Entretanto, também poderia ter dito que sim, se fossem levadas em conta tantas das tramas que o presépio narra.

A história do Pipiripau é conhecida. Raimundo Machado Azeredo começou a construí-lo em 1906, aos doze anos, e essa obra foi sendo feita por toda sua vida, que terminou em 1988. Comprado pela Universidade Federal de Minas Gerais em 1983 e tombado pelo IPHAN em 1984, desde 1976 localiza-se no Museu de História Natural da UFMG. Antes disso, era exposto regularmente na casa de seu criador, em algumas ocasiões no Parque Municipal, como o atesta uma fotografia da década de 1940, ${ }^{1}$ além de ter sido levado a São Paulo, em 1954, quando foi escolhido pela Comissão Mineira de Folclore para representar este estado nas comemorações do IV $^{\circ}$ centenário daquela cidade.

${ }^{1}$ CAMPOS. Raimundo Machado, p.18-19. 
Entretanto, academicamente, muito pouco se tem escrito sobre ele. No que se escreveu, destacam-se sua descrição e parte das declarações de seu criador, feitas em entrevista à Profa. Dra. Vera Alice Cardoso Silva, em 1984, ${ }^{2}$ sobre as primeiras peças, a escolha e composição das cenas ou os materiais empregados. Nesse sentido, tanto o livro organizado por Adalgisa Arantes Campos, Raimundo Machado, como o de Mônica Meyer, Pipiripau: Presépio - Movimento, oferecem-nos um registro criterioso dos documentos disponíveis.

Como nos informa Campos, o Presépio "apresenta 45 cenas, 580 figuras dispostas em um cenário de cinco planos, relacionados por uma rampa ascensional”, ${ }^{3}$ em um espaço de $20 \mathrm{~m}^{2}$. Reportando-se ao inventário do material utilizado, feito pelo restaurador Antônio Fernandes Batista dos Santos por ocasião do processo de tombamento, é a autora ainda quem fornece a seguinte relação: "As figuras e adornos são feitos de diversos materiais: gesso, papier-mâché, madeira, eucatex, tecidos, plásticos, vidrinhos, conchinhas, sucatas variadas, vegetação natural e artificial". ${ }^{4}$ Nessa lista, expressa-se pelo menos uma das principais características do Pipiripau: não se pode classificar a diversidade do material utilizado sem recorrer a expressões populares ("vidrinhos") ou a generalizações ("plásticos", "sucatas variadas"). Dito de outra maneira, o Pipiripau reúne as sobras da cidade: cata e cola seus cacos, superpondo camadas de diferentes idades e procedências.

O mesmo se dá com a descrição do mecanismo que o movimenta, nas palavras de Meyer:

Três eixos principais saindo da roda motriz dão ciência ao Pipiripau. As peças da engrenagem são de sucata: carretéis de madeira, rodas de ferro de antigas máquinas de costura, velas descartáveis de automóveis, pedacinhos de arame, barbante e linha, retalhos de madeira, latas e tantas outras quinquilharias readquirem novos usos. ${ }^{5}$

Esses dois livros são ilustrados com fotos do Presépio, de diferentes autores, que privilegiam alguns recortes ou que tentam abarcá-lo de forma panorâmica. Na maioria dos casos, o plano bidimensional ou o recorte escolhido acabam por revelar a dificuldade de se apreendê-lo: quando se focalizam as partes, sobram, nas margens ou no fundo, os liames narrativos que se estendem a outros quadros, ou cortam-se pedaços das imagens focalizadas. Quando se tenta uma visão do todo (Fig. 1), termina-se por evidenciar o excesso de figuras no espaço delimitado. Isso considerado, talvez as mais bem sucedidas dessas fotos sejam algumas das que fez William Golino ${ }^{6}$ quando apresenta a imagem desfocada, imprecisa, mas, por isso mesmo, mais propensa a expressar o alto grau de sugestão que nos vem do Pipiripau. É também interessante a solução apresentada no livro de Meyer: um convite para o leitor fazer deslizarem as páginas rapidamente pelo polegar, "animando" três figuras, fotografadas por Sylvio Coutinho.

\footnotetext{
${ }^{2}$ Apud CAMPOS. Raimundo Machado, p. 91.

${ }^{3}$ CAMPOS. Raimundo Machado, p. 87.

${ }^{4}$ CAMPOS. Raimundo Machado, p. 88.

${ }^{5}$ MEYER. Pipiripau, p. 26.

${ }^{6}$ CAMPOS. Raimundo Machado, p.12-13 e p. 35.
} 


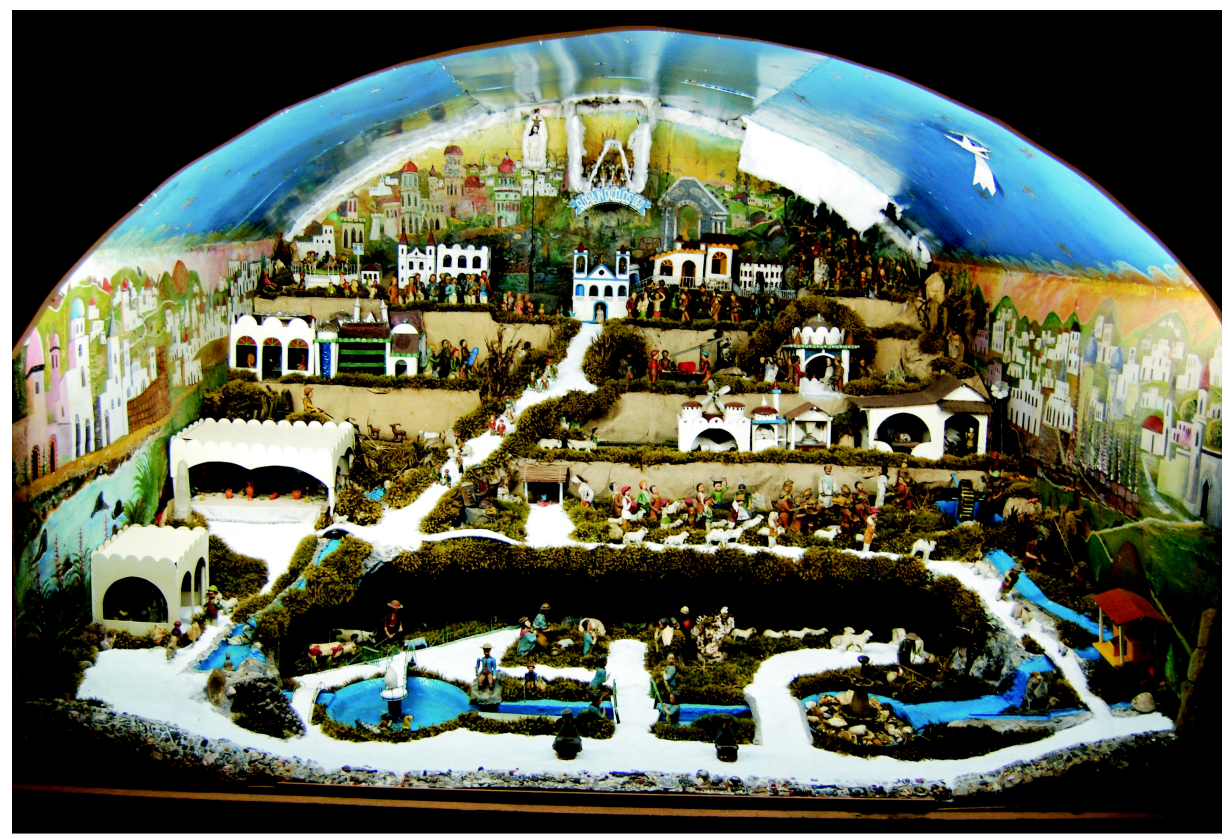

Fig. 1: Raimundo Machado Azeredo (1894-1988), O Presépio do Pipiripau. Belo Horizonte:

Museu de História Natural da UFMG. Foto: Claus Clüver. Cf. Prancha 9, p. 381.

Do texto de Campos, destaco ainda uma avaliação dessa obra:

Ela articula, com surpreendente criatividade, a fé, o fazer e o conceber, a história de Belo Horizonte e do próprio processo de modernização tecnológica, dos materiais e das mentalidades. [...] O Pipiripau é a obra mais representativa das manifestações da arte popular de Minas Gerais, isto é, tem uma grande sustentação antropológica, contudo supera esse próprio enquadramento porque é popular, universal e particular a um só tempo. ${ }^{7}$

Outras leituras, de outra natureza, contemplam o Presépio.

Em 1927, Carlos Drummond de Andrade, assinando como Antonio Chrispim, publica no Diário de Minas o poema "Pipiripau", ${ }^{8}$ que o recorta com delicadeza. Nesse poema, insiste no uso do diminutivo, em consonância com o tamanho das imagens e com o espaço reservado à criança nessa obra: "Os musicos tocam baixinho / Uma suave musica fininha / Que sobe prás estrellinhas", ou "Gira e regira na praça / A eterna zanga-burrinha. / - tão engraçadinha!" Explora a repetição, sublinhando o frenético movimento das figuras ("entram na igreja e saem depressa. / E tornam a entrar. / (E tornam a sahir)"), efeito que também obtém pela insistência das rimas ou pela pontuação, como nos parênteses do verso transcrito, ou na ausência de vírgula: "ferreiros sapateiros mexendo". Empresta-lhes, ainda, o movimento de seu olhar: "A calma das casas subindo a ladeira, / descendo a ladeira".

Quando publica Boitempo (1968-1973-1979), livro eminentemente memorialista, propõe uma releitura no "Presépio Mecânico do Pipiripau", ${ }^{9}$ poema em que acentua o entrelaçamento da cidade de Belo Horizonte à paisagem do Presépio: do "bairro com alguma coisa de rural", "Jesus aciona todas as forças / do homem. Ninguém parado".

${ }^{7}$ CAMPOS. Raimundo Machado, p. 89-90.

${ }^{8}$ ANDRADE. Pipiripau.

${ }^{9}$ ANDRADE. Presépio Mecânico do Pipiripau. 
Assim, quando acrescenta: "Organiza-se a indústria em seu redor", tanto o poeta pode estar se referindo a uma quanto ao outro. Reutiliza o recurso da ausência de vírgula: "Tudo nasce tudo mexe, tudo gira / em torno do menino sobre o capim mimoso" e acrescenta um toque de ironia: "Lutadores de boxe trocam murros / para maior glória do menino". Com a autoridade do traço poético, confere-lhe um título emblemático: "Pipiripau, presépio modernista 1927".

No gesto de entrelaçar a causa defendida pela primeira geração do Modernismo ao Presépio do Pipiripau - através dos recursos utilizados no primeiro poema, referendados implícita e explicitamente pelo segundo - Drummond passa a ter seu nome ligado a essa história. No Museu, o poema "Pipiripau" encontra-se em destaque, ao lado da vitrine de $2 \times 1 \mathrm{~m}$ que dá a ver a mecânica do Presépio, e em pelo menos dois livros - o de Adalgisa Arantes Campos, já citado, e o de Geruza Helena Borges, intitulado O Presépio do Pipiripau - foi transcrito no todo ou em parte, como referência indissociável.

É também Drummond quem motiva o olhar de Cyro dos Anjos e de Pedro Nava para a obra. Cyro dos Anjos, em 1930, também no Diário de Minas, afirma não ter ido ver o Presépio, embora o deseje desde que seu amigo Drummond fez dele um tema poético, ${ }^{10}$ mas, ainda assim, fornece uma descrição minuciosa:

Creio commovidamente no que me dizem a respeito do presepio de Pipiripáo. E dizem coisas extraordinarias. Há minusculas procissões que vão e vêm, ha locomotivas que correm, apitam e param quando tem boi na linha. Ha homens pastoreando rebanhos, ha uma notavel confusão de seculos, de edades, de usos e costumes. A Judéa dos lagos biblicos com a Norte America em plena exuberancia de civilização. O tempo dos pharaós com o tempo das formulas fascistas e comunistas. A edade media se confraternizando com a edade préhistórica e a contemporanea. ${ }^{11}$

Observam-se, no trecho, os pontos aumentados por quem contou essa história, mas, principalmente, a precisão com que se assinala a profusão de tempos e lugares que convivem nesse universo, em uma perspectiva que, na época, parece ter sido vista como antropofágica. Do trecho, cabe destacar a fabulação induzida pelo Presépio que convida o leitor a inserir, com seu olhar, o que do mundo contemporâneo poderia ter estado lá, harmonizado com a história bíblica. Nesse depoimento, Cyro dos Anjos também eleva o Presépio a ícone: um "monumento à confusão brasileira"12 das raças e culturas.

Tudo leva a crer que Drummond efetivamente conduziu muitos dos intelectuais da época a visitarem o Pipiripau, como Pedro Nava registra, em Beira-mar:

Toda essa Floresta era dos meus itinerários de menino e depois o foi outra vez, dos de rapaz, quando ia visitar Carlos Drummond ou quando com ele, Emílio Moura e Martins de Almeida subimos os detrás do Colégio Santa Maria e fomos, dentro do mato grosso das Minas e sua noite preta adentro, descobrir o Brasil no Presépio do Pipiripau. ${ }^{13}$

\footnotetext{
${ }^{10} \mathrm{http}: / /$ orbita.starmedia.com/ presepiopipiripau/hppres4.htm

${ }^{11} \mathrm{http}: / /$ orbita.starmedia.com/ presepiopipiripau/hppres $4 . \mathrm{htm}$

${ }^{12} \mathrm{http} / / /$ orbita.starmedia.com/ presepiopipiripau/hppres $4 . \mathrm{htm}$

${ }^{13}$ NAVA. Beira-mar, p. 258.
} 
Novamente o Pipiripau se associa à proposta da primeira geração modernista, agora sob o designo de dar a ver o Brasil em seu engenho. Dessa forma, respalda-se a decisão de torná-lo figura emblemática desse movimento em Minas Gerais, provavelmente à revelia de seu criador que, ao que tudo indica, desconhecia teorias a esse respeito e atribui a "uma mudança na fé" o fato de as pessoas irem visitar o Pipiripau "por curiosidade". ${ }^{14}$ Na realidade, os textos de Carlos Drummond de Andrade e de Cyro dos Anjos não são citados no depoimento em que Raimundo Machado destaca a primeira fotografia do Pipiripau, feita pelo "senhor Junqueira", ${ }^{15}$ em 1922, e a primeira reportagem, escrita por José Romeu dos Santos, ${ }^{16}$ no semanário A Tribuna.

Por ocasião dos 90 anos do Presépio, Geruza Helena Borges publica O Presépio do Pipiripau, acima mencionado. O livro é ilustrado com fotografias de suas pranchas construídas em caixas de madeira com imagens confeccionadas por conjuntos de bastonetes em papel crepom, nas quais se apresentam as imagens do Pipiripau, onde sua leitura inscreveu novos elementos, como o trem de Cyro dos Anjos, com seu boi na linha, ao lado da Igreja de São Francisco, ${ }^{17}$ gesto que transcreve a emblemática obra de Niemeyer e Portinari para o universo de Raimundo Machado, dando continuidade a sua tradição de incrustar a cidade no mundo que construiu. Se as imagens promovem uma leitura delicada e expressiva do Pipiripau, o texto de Borges apenas as acompanha com uma breve descrição do Presépio e referências a sua história, acrescida da citação de trechos de Drummond e de Cyro dos Anjos.

Mais recentemente, em 2001, contamos com um cordel de Olegário Alfredo, A História do Presépio Pipiripau, no qual ele é considerado "um presente para o mundo". ${ }^{18}$ O poeta cita a tradição católica de se construírem presépios particulares, descreve as figuras que mais lhe chamam a atenção no Pipiripau, narra brevemente a história de seu criador, da confecção do Presépio e de seu tombamento, dá sua localização atual e incita o leitor: "Venham todos, venham ver". ${ }^{19}$ Inscrevendo-se na melhor linhagem da Literatura de Cordel, o livreto apresenta uma leitura singela das imagens que recorta, afinada com a voz do próprio Raimundo Machado.

$\mathrm{Na}$ segunda edição, de 2004, criou-se uma segunda versão para a capa. Repetese em alguns exemplares o desenho de Evaristo Barbosa, e apresenta-se a xilogravura de Costa Leite. Destaca-se a primeira dessas ilustrações, que expõe, em um único plano, a cena da criança deitada na manjedoura e as engrenagens que movimentam o Pipiripau, conseguindo, assim, uma leitura mais próxima da obra em questão. Na segunda, há um presépio convencional, exibindo com traços fortes e estilo característico de seu criador a cena da visita dos Reis Magos.

Quando nos reportamos às imagens, independente de qualquer juízo de valor sobre a qualidade dessas obras, a mais importante, para o Presépio, é a de Francisco

${ }^{14}$ CAMPOS. Raimundo Machado, p. 51.

${ }^{15}$ CAMPOS. Raimundo Machado, p. 24.

${ }^{16}$ CAMPOS. Raimundo Machado, p. 26.

${ }^{17}$ BORGES. O Presépio do Pipiripau, p. 5-6.

${ }^{18}$ ALFREDO. História do Presépio Pipiripau, p. 5.

${ }^{19}$ ALFREDO. História do Presépio Pipiripau, p. 3 e p. 6. 
Lino, que compõe a cena do Pipiripau com uma cidade, marcada pela profusão de estilos arquitetônicos, que se integra ao presépio como uma moldura, constituindo também suas margens. Sua maior relevância deriva do fato de ter sido incorporada ao Presépio por uma opção de Raimundo Machado, e, em conseqüência, hoje vemos o Pipiripau enquadrado por ela, no local onde está exposto.

Outro formato de leitura foi feito em 1988 através do curta-metragem Nascimento, paixão e morte segundo Pipiripau, dirigido por José Adolfo Moura, como parte de sua dissertação de Mestrado na Escola de Comunicação e Artes da USP. O filme apresenta trechos do depoimento do criador do Pipiripau, mesclando imagens de Raimundo Machado em sua casa, trabalhando em figuras do Presépio e andando por Belo Horizonte. Traz ainda um trecho do texto de Cyro dos Anjos, lido pelo próprio autor, e uma trilha sonora com músicas de "pastorinhas" da região da grande Belo Horizonte, que costumam visitar até hoje o Pipiripau nos meses de dezembro e janeiro. Registra-se, assim, o entrelaçamento dos dois cânones, o dos autores consagrados e o popular, que têm contemplado o Presépio nos últimos cem anos. Dos recursos utilizados na filmagem, quero ressaltar o efeito obtido pela focalização de um caçador no momento dos "trovões" produzidos para assinalar a morte de Cristo, recorte que evoca os vários deslocamentos do olhar, caracterizando a maneira como as histórias se misturam no cenário.

Promover uma leitura através de um filme é, sem dúvida, uma homenagem relevante ao criador do Pipiripau, um amante do cinema cujas técnicas, em certa medida, influenciam sua obra. Para Campos, "Difícil distinguir onde está a influência direta da tradição religiosa, dos ofícios mecânicos, da arte cinematográfica, da engenharia em geral". ${ }^{20}$

Visto a partir da perspectiva dos estudos da intermidialidade, poderíamos dizer que Presépio do Pipiripau não é literatura que se faz com letras: para registrar essa maneira de ler ou ouvir os relatos bíblicos, outras mídias foram recrutadas. É através de pequenas esculturas que se movimentam mecanicamente pelo cenário representado no Presépio, que a obra de Raimundo Machado registra as muitas versões das várias histórias colhidas na tradição oral e escolhidas pela memória e pela imaginação. Invertendo esse percurso, ali já estão as histórias que ele nos faz contar, e os vários trabalhos que se produziram a partir do Presépio do Pipiripau nos dão o testemunho do convite à fabulação que ele nos transmite. Estes, por sua vez, utilizam também diversas mídias, como os registros feitos em imagens visuais ou audiovisuais, assim como os textos que se escreveram a partir da representação proposta por Raimundo Machado. Essas narrativas transformamse em literatura quando se consegue dar a elas a tensão necessária, como o fizeram Drummond, Cyro dos Anjos ou Olegário Alfredo. O objetivo deste texto é registrar uma leitura à luz da teoria literária, pontuando as várias histórias que nele se entrelaçam, não para suprir essa lacuna; antes, talvez, para evidenciá-la, apontando o muito que se pode produzir nesse sentido.

O caráter narrativo do Presépio insinua-se pelo fio da história bíblica, acentua-se pelo movimento das figuras e atinge seu ápice quando ouvimos o som de trovões, seguidos pelos efeitos de iluminação. Esse recurso confere ao Pipiripau um caráter de teatro de bonecos, diante da evidência de que não estamos em presença de várias figuras que

${ }^{20}$ CAMPOS. Raimundo Machado, p. 89. 
possam ser percorridas pelo olhar em qualquer direção e pelo tempo que nos aprouver. Em outras palavras, os trovões quebram a concomitância das cenas apresentadas, porque se pressupõe que o espectador esteja, naquele momento - oito minutos depois que o Presépio está em movimento - observando a representação do Monte Calvário. Vale acrescentar que, contrariando a tradição pictórica ocidental - do centro para as margens - as figuras narram a história em ziguezague, da esquerda para a direita e de baixo para cima, da gruta onde o Menino nasceu até o alto, puxando o olhar pela ascensão da imagem de Cristo, completando o ciclo que o calendário cristão repete a cada ano. Cabe assinalar que, mesmo nesse percurso, não há uma cronologia rígida, superpondose os tempos no cenário.

Esse movimento do olhar que acompanha a narrativa bíblica percorre alguns ícones de Belo Horizonte, construindo a contrapelo uma história da cidade vista desde as bordas, de uma perspectiva localizada no que era então sua periferia. Nessa combinação singular, Cristo nasce próximo ao Parque Municipal, e os traços barrocos de uma igreja saem de alguma antiga cidade mineira - talvez de Matozinhos, onde Raimundo nasceu - para integrar o cenário da nova capital. Dos resultados dessa desconstrução, o mais sugestivo me parece ser o que ocorre com o obelisco conhecido como "pirulito" da Praça Sete, que vem instalar-se ao lado da Santa Ceia, à margem esquerda do Presépio. Dá-se aí uma inversão de perspectiva que localiza precisamente o leitor na região do Pipiripau, centro marginal que desloca as referências da cidade.

Enquanto as representações bíblicas seguem sua cronologia truncada, as imagens de Belo Horizonte escolhidas pelas lembranças de Raimundo Machado vão espalhar-se ao sabor da fantasia. Sabe-se, por seus depoimentos, que elas vão sendo acrescentadas concomitantemente à representação da outra história. Assim, por volta de 1910, depois de construir uma gruta para o nascimento de Cristo, acrescenta uma lagoa - a primeira cena a ser animada, manualmente. Do movimento dessa água, vem o desejo de construir as novas peças:

Fiquei com vontade de fazer o pescador e o moinho de fubá. Na estrada da Colônia [Américo Werneck], hoje rua Pouso Alegre, tinha um senhor chamado Capitão Castro. O Capitão Castro tinha um moinho onde hoje é a avenida Silviano Brandão, aqui no Horto. Eu levava milho daqui pra trocar por fubá com ele. Então, ficava olhando o moinho trabalhar e tive a idéia de fazer aquele moinho, em miniatura, mas tocado à água. ${ }^{21}$

Para acompanhar, então, essa história pessoal, localizada com precisão no mapa de Belo Horizonte, é necessário que aquele que contempla o Presépio recrie uma narrativa para as personagens e lugares que se oferecem na paisagem, preenchendo as lacunas com sua própria experiência.

De situar-se nessa zona limítrofe, Raimundo extrai o lugar onde inserir sua história pessoal no quadro que compunha. Seu depoimento percorre a cidade marcando sempre os nomes antigos e recentes de suas ruas e praças, utilizando uma linguagem também característica da região de onde fala. Assim, por exemplo, ele diz que "ia mais mamãe

${ }^{21}$ CAMPOS. Raimundo Machado, p. 18. 
na Igreja São José”, onde viu o presépio que o motivou, e, em sua dicção, as garrafinhas que vendeu para comprar a primeira figura eram de óleo de "riço", e não de rícino. ${ }^{22}$

Dessa perspectiva, uma das maiores riquezas dessa obra está nas esquinas que se formam para entrelaçar as três narrativas: a história bíblica, uma autobiografia e uma história de Belo Horizonte. Mesmo a primeira delas traz a Escritura permeada da tradição oral, o que se verifica, por exemplo, na cena em que dois homens estão colocando ferraduras invertidas no burrinho que leva José, Maria e Jesus em sua fuga para o Egito: o gesto que pretende enganar os perseguidores é abençoado por um anjo que sobe e desce na cena. Também há lugar para a figura do Papai Noel, ao lado de um pau-desebo, comum nas festas juninas de então. A narrativa autobiográfica não evidencia uma cronologia: as figuras vão sendo construídas e espalhadas pelo cenário, ausência e presença de uma história registrada ao longo de tantos anos, em que o que se narra é tão importante como a forma encontrada para animar a obra, as soluções plásticas ou mecânicas, colhidas nas várias profissões que seu criador exerceu. A terceira história, a de Belo Horizonte, reconstitui-se de uma perspectiva afetiva, narrada com a linguagem suburbana e a autoridade do testemunho.

A partir da teoria de Walter Benjamin, Heloísa Starling descreve o subúrbio como sendo aquilo que

serve para conformar o fino traço do que poderia ser chamado, por analogia e contraste, como uma zona limítrofe entre o que ainda é tão recente que não foi tocado por nenhuma história, tão deteriorado que não chegou a envelhecer, tão inédito que não conseguiu nascer e está morto, tão novo que algo nele permanece à espera de conclusão. ${ }^{23}$

Por essa fímbria, o Presépio do Pipiripau é um desses raros momentos em que a história do subúrbio se registra. Utilizando como ferramenta uma das propostas da teoria desenvolvida por Ricardo Piglia, em que o autor assinala uma tensão entre as ficções do Estado e as narrativas populares ${ }^{24}$ podemos confrontar pelo menos duas histórias de Belo Horizonte. Uma, a que se conta no Pipiripau; outra, a que direciona o planejamento da cidade. Do cruzamento entre as duas, gostaria de recortar três nomes: o do Presépio, os nomes de uma avenida e o da própria cidade.

Essa avenida localiza a região do Pipiripau para além do contorno excludente de sua proposta, e até hoje é batizada oficialmente de Dezessete de Dezembro, nome praticamente desconhecido da população. Alusivo à data da promulgação da lei $\mathrm{n}$ o 3 , adicional à Constituição Mineira, que definia o local - arraial de Bello Horizonte para nele se construir a Capital, sequer consta das placas de sinalização do logradouro. Segundo Leonardo José Magalhães Gomes: "Exceto na documentação oficial dos primeiros tempos da cidade, até a década de 1940 aproximadamente, o nome Dezessete de Dezembro foi pouco usado. O próprio Aarão Reis, que a batizou, usa em muitos de seus documentos o termo Avenida do Contorno". ${ }^{25}$ O nome popular lê com clareza o

\footnotetext{
${ }^{22}$ MOURA. Nascimento, paixão e morte segundo Pipiripau.

${ }^{23}$ STARLING. Cartografia do subúrbio, p. 4.

${ }^{24}$ PIGLIA. Tres propuestas para el próximo milênio (y cinco dificultades). p. 21.

${ }^{25}$ GOMES. Memória de ruas, p. 88.
} 
que propunha o projeto: circunscrever a zona urbana, para a qual viriam, a contragosto, os funcionários públicos de Ouro Preto, acompanhando o deslocamento do corpo administrativo a que estavam vinculados.

O nome escolhido para a nova capital foi Cidade de Minas, que consta na planta de 1895 e demais documentos oficiais da época. Entretanto, se foi possível e relativamente simples desapropriar e demolir as casas do arraial, o nome antigo não pôde ser mudado e foi oficializado em 1 de Julho de $1901 .^{26}$

É do fantasma do antigo arraial que o Pipiripau vem nos dar o testemunho, ele próprio batizado pelo espaço que ocupava na cidade: a região que compreendia os bairros Floresta, Horto, Sagrada Família e Santa Tereza. ${ }^{27}$ Pipiripau é um neologismo, criado a partir do nome de uma planta da região, pipiri, ou piripiri, designação de origem indígena para uma espécie de junco. ${ }^{28}$ A planta cedeu lugar ao cimento, o mapa social da cidade mudou, mas o nome vernacular resiste no Presépio.

Algumas dessas narrativas, que insistem na voz de um corpo social que fala nas entrelinhas, estão registradas no Pipiripau, não apenas por seu caráter ficcional, mas pela forma com que as entrelaça. Para ajustar o foco desta leitura, recorro às propostas de Italo Calvino e de Ricardo Piglia para este milênio. Como se sabe, as do primeiro são a Leveza, a Rapidez, a Visibilidade, a Multiplicidade e a Exatidão, ${ }^{29}$ e as do segundo, que lhe segue os passos desde este subúrbio do mundo ${ }^{30}$ em que nos encontramos, são Verdade, Deslocamento e Claridade.

A Leveza, no Presépio, destaca-se imediatamente pela delicadeza de sua construção, em resposta "ao peso do viver" ${ }^{11}$ da periferia, o que já muda, também, o ponto de observação da história da cidade e da história bíblica. Reconstituída a partir de recortes, a história que se encena no Pipiripau é rarefeita, e um valor emblemático incide sobre as imagens. Dessa perspectiva, é com passos de dança que o olhar a acompanha, em sua modulação lírica.

Negligenciando elementos inúteis, Raimundo Machado promove a combinação das narrativas que entrelaça à história bíblica, de sorte a que "rimem entre si" (p. 49), como quer Calvino ao descrever a Rapidez. Coincidência ou não, é em ziguezague que essa narrativa se desenrola (p. 48), carregando histórias dentro de histórias. Além dos cruzamentos já apontados, não entrevemos um presépio dentro do Presépio, na Igreja de São José, onde uma fila de fiéis entra e sai (e torna a sair)? Um dos músicos representados não seria o próprio Raimundo, que tocava trombone na banda da Floresta?

A tensão entre as histórias trançadas - a universalidade de uma e a particularidade de outras - evoca em contracanto a história oficial. Todas elas se fazem ouvir, em uníssono ou dissonância, com a Exatidão necessária para se captar o vago (p. 75), traço que

\footnotetext{
${ }^{26}$ GOMES. Memória de ruas, p. 10.

${ }^{27}$ CAMPOS. Raimundo Machado, p. 76.

${ }^{28}$ HOUAISS. Dicionário eletrônico Houaiss da língua portuguesa.

${ }^{29}$ CALVINO. Seis propostas para o próximo milênio.

${ }^{30}$ PIGLIA. Tres propuestas para el próximo milênio (y cinco dificultades), p. 12.

${ }^{31}$ CALVINO. Seis propostas para o próximo milênio, p. 39. Todas as demais citações desta obra virão seguidas do(s) número(s) da(s) página(s) na(s) qual(is) se encontram.
} 
subjaz na cidade que se representa, onde cada imagem compõe uma cena, participa da que lhe está próxima e elabora textos curtos que, desconhecendo hierarquias, trançam um enredo aberto que inclui e exige a participação do espectador.

Tratando da Visibilidade, Calvino define: "A fantasia é uma espécie de máquina eletrônica que leva em conta todas as combinações possíveis e escolhe as que obedecem a um fim, ou que simplesmente são as mais interessantes, agradáveis ou divertidas" (p. 107). No caso do Pipiripau, seria difícil decidir qual dessas duas opções prevalece, uma vez que aparentemente há um fim, que é o de entrelaçar à história bíblica as cenas do cotidiano, mas também é forte o desejo de ali se acrescentar toda e qualquer figura que atendesse ao objetivo de tornar o conjunto "interessante, agradável e divertido".

Ainda desenvolvendo essa proposta, Calvino observa que, antigamente, o artista contava com suas experiências e um reduzido repertório de cultura, enquanto, hoje, teria "estratos sucessivos, mil estilhaços de imagem, semelhantes a um depósito de lixo" (p. 107). O lixo é um dos lugares privilegiados onde Raimundo Machado encontra o que acrescentar a sua obra. Basta olharmos o frontispício do Presépio onde estão dispostos objetos como uma chave, molas, moedas, contas e conchas, restos de artefatos agora irreconhecíveis, bem como as letras VW e Be, deslocadas de suas respectivas logomarcas e das palavras que formavam, para verificar que a seleção dos elementos ali incrustados deve muito a uma combinação entre o acaso e o gosto estético de seu criador.

Finalmente, ao propor a Multiplicidade, Calvino observa a semelhança entre o romance contemporâneo e a enciclopédia, "rede de conexão entre os fatos, entre as pessoas, entre as coisas do mundo" (p. 121). O Presépio do Pipiripau expõe a nossos olhos a arquitetura dessa espécie de romance: uma enciclopédia aberta, onde as tensões entre as histórias se arranjam. Um brinquedo, um jogo, um registro, onde se verifica que: "Cada vida é uma enciclopédia, uma biblioteca, um inventário de objetos, uma amostragem de estilos, onde tudo pode ser continuamente remexido e reordenado de todas as maneiras possíveis" (p. 138).

O Presépio salienta-se do subúrbio, testemunhando essa zona onde se vive do potencial ou, ainda nas palavras de Calvino, "de tudo quanto não é, nem foi e talvez não seja, mas que poderia ter sido” (p. 106). Situando a América Latina como lugar de onde se lança um olhar levemente marginal ${ }^{32}$ para a cultura européia, Ricardo Piglia apresenta o Deslocamento como a sexta proposta, suplementado a teoria de Calvino. ${ }^{33}$ Em outra publicação, Tres propuestas para el próximo milênio (y cinco dificultades), apresenta, também, a Verdade e a Claridade.

Acredito que o Deslocamento seja o eixo central, alocado, como está, na posição de segunda proposta nessa outra versão. A partir dele, interpõe-se um outro relato ao que se quer mostrar, para que se possa transmitir a experiência que não se pode expressar diretamente. O Deslocamento possibilita, então, contar "ese punto ciego de la experiencia, mostrar lo que no se puede decir", ${ }^{34}$ tomando-se distância do indizível. Ainda para Piglia, "Los vencedores escriben la historia y los vencidos la cuentan. Ése

\footnotetext{
${ }^{32}$ PIGLIA. Tres propuestas para el próximo milenio, p. 13.

${ }_{33}$ PIGLIA. Una propuesta para el nuevo milenio.

${ }^{34}$ PIGLIA. Tres propuestas para el próximo milenio, p. 33.
} 
sería el resumen: desmontar la historia escrita y contraponerle el relato de un testigo". 35 Nessa tensão entre os relatos se encontra a Verdade, por ele considerada como "horizonte político y objeto de lucha". ${ }^{36} \mathrm{Na}$ esteira de Lacan, Piglia identifica na Verdade a estrutura de uma ficção e propõe "Hacer en el lenguaje un lugar para que el otro pueda hablar". ${ }^{37}$

Nesse contexto, a Claridade vem confrontar o discurso oficial e sua obscuridade deliberada: "En momentos en que la lengua se ha vuelto opaca y homogénea, el trabajo detallado, mínimo, microscópico de la literatura es una respuesta vital". ${ }^{38}$

Uma leitura dessas histórias tramadas em tantas linguagens, produzidas por meios tão diversos, à luz dos estudos literários contemporâneos, como espero ter demonstrado, acrescentam uma nova dimensão à recepção do Presépio do Piripipau. Outras abordagens de análise, na área de estudos literários ou em outras disciplinas acadêmicas que possam se interessar por essa obra mixmídia, irão, certamente, resultar em leituras diferentes. Entretanto, todas elas traduzirão, em termos lingüísticos, esse texto sem palavras. Para deixar em aberto essa proposta, encerro retomando Calvino:

A palavra associa o traço visível à coisa invisível, à coisa ausente, à coisa desejada ou temida, como uma frágil passarela improvisada sobre o abismo. (...) Por isso o justo emprego da linguagem é, para mim, aquele que permite o aproximar-se das coisas (presentes ou ausentes) com discrição, atenção e cautela, respeitando o que as coisas (presentes ou ausentes) comunicam sem o recurso das palavras. (p. 90-91)

\section{A4}

\section{A B S T R A C T}

This paper proposes a reading of the Presépio do Pipiripau, in light of the literary pieces published about it, as well as other readings made through pictures, paintings or movies. Using Italo Calvino's and Ricardo Piglia's theories, I argue that it is possible to read several stories interwoven in Pipiripau, in the light of literary theory and the study of intermediality.

\section{KEYWORDS}

"Modernist"nativity scene, folklore, (hi) story(ies), readings, verbal and visual re-presentation, literary theory

\footnotetext{
${ }^{35}$ PIGLIA. Tres propuestas para el próximo milenio, p. 29.

${ }^{36}$ PIGLIA. Tres propuestas para el próximo milenio, p. 30.

${ }^{37}$ PIGLIA. Tres propuestas para el próximo milenio, p. 37.

${ }^{38}$ PIGLIA. Tres propuestas para el próximo milenio, p. 41.
} 


\section{REFERÊNCIAS}

AlfredO, Olegário. A História do Presépio Pipiripau. Belo Horizonte: SESC - BH, 2001. ANDRADE, Carlos Drummond de. Pipiripau. Diário de Minas. Belo Horizonte, p. 1, 30 jan. 1927.

ANDRADE, Carlos Drummond de. Presépio Mecânico do Pipiripau. In: Poesia Completa. Volume único. Rio de Janeiro: Nova Aguilar, 2002, p. 1138.

ANJOS, Cyro dos. O Presépio Brasileiro do Pipiripáu. Diário de Minas. Belo Horizonte, 25 dez. 1930. http://orbita.starmedia.com/ presepiopipiripau/hppres4.htm. Acessado em: 6 fev. 2006.

BORGES, Geruza Helena. O Presépio do Pipiripau. Belo Horizonte: Terra Editoria, 1996. CALVINO, Italo. Seis propostas para o próximo milênio: Lições americanas. Trad. Ivo Barroso. São Paulo: Companhia das Letras, 1990.

CAMPOS, Adalgisa Arantes (Org.). Raimundo Machado. Belo Horizonte: C/Arte, 2003. GOMES, Leonardo José Magalhães. Memória de ruas. Dicionário toponímico da cidade de Belo Horizonte. Belo Horizonte: Secretaria Municipal de Cultura / Museu Abílio Barreto, 1992.

HOUAISS, Antônio. Dicionário eletrônico Houaiss da língua portuguesa. São Paulo: Objetiva, 2001.

MEYER, Mônica. Pipiripau: Presépio movimento. Belo Horizonte: Museu de História Natural e Jardim Botânico da UFMG, 2004.

NASCIMENTO, PAIXÃO E MORTE SEGUNDO PIPIRIPAU. Direção José Adolfo MOURA. Belo Horizonte: Centro Audiovisual / UFMG e Departamento de Fotografia e Cinema da Escola de Belas Artes da UFMG, 1988. Curta-metragem em 35mm.

NAVA, Pedro. Beira-mar: memórias. 4. ed. Rio de Janeiro: José Olympio, 1979.

PIGLIA, Ricardo. Una propuesta para el nuevo milênio. Revista Margens. Belo Horizonte / Mar del Plata / Buenos Aires: Editora UFMG, n. 2, p. 1-3, outubro de 2001.

PIGLIA, Ricardo. Tres propuestas para el próximo milênio (y cinco dificultades). Buenos Aires / México: Fondo de Cultura Económica, 2001.

PIGLIA, Ricardo. El último lector. Barcelona: Anagrama, 2005.

STARLING, Heloísa. Cartografia do subúrbio. Revista Margens. Belo Horizonte / Mar del Plata / Buenos Aires: Editora UFMG, n. 2, p. 3-5, outubro de 2001. 